\title{
The Importance of Involving the Cultural Background to Handle Covid-19 in Indonesia
}

\author{
Sri Poedjiastoeti*, Sri Ratna Suminar \\ Faculty of Law \\ Universitas Islam Bandung \\ Bandung, Indonesia \\ *sri.poedjiastoeti@unisba.ac.id, sri.ratna@unisba.ac.id
}

\begin{abstract}
The number of people exposed to Covid-19 on a national scale is still high and it began to growing attention from the scientific community. The spread of Covid-19 is difficult to stop from countries around the world. Indonesia, which territory is so vast and has diverse cultures, must be comprehensively to prevent the virus spreads. Still, high people are exposed to Covid19 because people do not comply with health regulations set by the government. This study uses a normative juridical research method with the anthropology of law approach, the data sources used obtained from literature studies, and analysis techniques obtained from literature and document studies. It is a challenge because of their non-compliance with health regulations. The people assume due to do not involve their culture in preventing the spread of Covid-19. The majority of Indonesian people remain to obey their culture because they are convenient for their culture or habits. The people will comply with the regulations that can prevent the spread of the virus whether involving their culture.
\end{abstract}

Keywords-Covid-19, Indonesian culture, compliance

\section{INTRODUCTION}

Almost all countries in the world today is fighting against Covid-19. Disease outbreaks caused by virus type a new severe acute respiratory syndrome corona virus 2 or SARS-Cov- 2 or also known as the Coronavirus. The Covid-19 started a plague in the city of Wuhan in China since December 2019. Corona Virus is a virus that attacks the respiratory system which can cause health problems ranging from mild disturbances of the respiratory system to severe disorders can even cause death.

Coronavirus has a higher level of risk. The outbreak of the disease is defined as a global pandemic by the World Health Organization (WHO) on March 11, 2020. The number of cases in the world until now, November 2020, reaching approximately 49,1 million cases [1] and new cases continue to occur in various countries.

In Indonesia, the government has set a plague Covid-19 as a national non-natural disaster based on Law Number 24 the Year 2007 on National Disaster. The number of positive cases Covid-19 in Indonesia, citing data from the Indonesian Ministry of Health until the month of November 2020, achieve
429.574 people with the details of amount recovered reached 360.705 people, and the victim died was recorded 14.442 people [2]. Based on the number of cases that occur around the world, Indonesia is in the 19 th position.

Indonesia to handle Covid-19 has its own challenges that are different from other countries. Indonesia has a vast territory with a wide variety of cultures with different conditions. Given such conditions necessarily requires a comprehensive treatment. To handle Covid-19 is to change people's behavior.

Government to deal with the pandemic in national legislation, namely Law No. 4 the Year 1984 on Epidemic Infectious Diseases, the Law Number 6 the Year 2018 on Health Quarantine, and Government Regulation Number 21 the Year 2020 about Restrictions on Large-Scale Social (PSBB). Government to speed up the handling Covid-19 has formed a Task Force of Acceleration Handling Covid-19 from the central to local levels. The government is also making efforts to prevent the spread and break the chain of transmission Covid19 to build awareness and invite the community adhere to the protocols of health, use of masks, frequent hand washing using soap, social distancing, physical distancing, Work from Home (WFH), worship at the home, and implement Restrictions on Large-Scale Social (PSBB).

However, efforts to prevent the spread and transmission of Covid-19 by the government still seems to be encountering obstacles. The legislation as written law became the basis of prevention efforts and the various recommendation or an appeal to prevent the spread and transmission of Covid-19 in the implementation has not been effective. The ineffectiveness in implementation caused by a variety of factors. When all the legal instruments and protocols of health enacted nationally, appeared a variety of reactions from the community. Some people who are not cooperative to the policy set by the government. Then, there is also the behavior of people who are not disciplined to carry out the protocol of health. People who are not cooperative and do not discipline because it is essentially influenced by economic factors, ideology, and culture [3]. Especially the policy of the government that the stipulation and its enforcement nationally without considering diversity and cultural differences in Indonesia. 
A lecturer at faculty of psychology, University of Gadjah Mada, said that changing people's behavior is not easy. According to her, every people will change their behavior if in accordance with the perception of what he believed in Kagama [4]. The perception of the community about the healthy and the sick affected by the socio-cultural. People's behavior can be changed into a particular way by managing behavior and culture regarding to the handling of Covid-19 in Indonesia.

\section{METHODS}

This research is a normative juridical, that is the method of approach with the use of secondary data as the main source of form of primary legal materials, secondary legal materials, and tertiary legal materials [5]. The material of the primary law is Law No. 4 the Year 1984 about the plague of Infectious Diseases, Law No. 62018 about Health Quarantine, and Law No. 21 the Year of 2020 about Restrictions on Large-Scale Social. Then, for legal materials secondary legal materials which are closely related to primary legal materials, among others, the opinion of legal experts, scientific books, articles papers, research results, journals, and literature of the internet. And, for legal materials tertiary, namely the materials of the law that provide guidance and clarification of primary legal materials and secondary legal materials such as legal dictionary, the Great Indonesian Dictionary, and encyclopedia

Once the data is collected. Firstly, the data will be redacted to minimize errors. After that, it will be classified according to its categories, which one will be das sollen and which one will be das sein. Then the data will be separated according to the variables in the title of the study. After that, the data arranged will be explained and evaluated in according to the framework of the problems addressed. Finally, a conclusion will be drawn in response to the problem that has been formulated [6]

\section{RESULTS AND DisCUSSION}

Plague Covid-19 has been attacking all the countries in the world. The WHO has set the Covid-19 as a pandemic. In the Great Indonesian Dictionary (KBBI) Ministry of Education and Culture, a pandemic is an outbreak that is spreading in unison everywhere, covering a wide geographical area [7], similarly, the government of Indonesia has set the Covid-19 as a national non-natural disaster.

Indonesia occupied the 19th position as the country which has cases of infection Covid-19. It shows that the number of people infected is quite high. To prevent the spread and transmission, the government in dealing with the outbreak Covid-19 should be comprehensive.

Chang [8] states that in the world there is no one country that is a monoculture, mono-religion, and mono-ethnic. Indonesia is a country that has a pluralistic society, that has a variety of tribes and each has a subculture. As a country that has cultural diversity, the founding fathers of Indonesia put it in the motto Bhinneka Tunggal Ika. The motto of the conceptual is a recognition of the existence of diversity and with a tendency to designate a nation as a unit of society [8].

Edward Burnett Tylor (1832-1917) formulated culture or civilization, taken in its wide ethnographic sense is that complex which include knowledge, belief, art, moral, law, custom, and many other capabilities and habits acquired by people as member of society" [9]. Culture which is so complex is a way of life that developed and owned by communities and inherited from generation to generation. The people are bound by the awareness of social systems and culture. That attachment is reflected from the way of life of the community, such as a certain pattern of behavior that can be distinguished from the patterns of behavior among the tribes.

The cultural diversity of Indonesia cannot be removable in dealing with the pandemic Covid-19 at this time. Handling to prevent the spread and transmission cannot be based only on medical treatment. Because given the perception of the people about healthy and sick regarding the social culture of the community.

In countermeasures, the Covid-19 government should consider socio-cultural factors and utilize the potential of culture and society. People do their culture from generation to generation. For that, the people have an attachment to the culture since birth in which they recognize some values.

Cultural values of the community are the crystallization of values that are recognized, understood, and appreciated by the community as something that became the foundation to behave in relationship with fellow human beings, the human relationship with God, and the human relationship with nature. That relation shows the specificity and uniqueness of a particular culture and reflects the way of life of the certain cultural community.

The government as a leader should have competence in a variety of things that are needed or desired by society and shall present it to the community [10]. The government is not able to prevent the spread and transmission of Covid-19 by applying the regulation on a national basis. Similarly, based on history, the handling of the outbreak of the disease could not be if done by involving only the medical aspects.

The government should consider that the cultural life of the community is a habit that has been tested naturally and trusted well worth it because the habit is a social action that is repeated and strengthened [10]. For example, when the government advocates to do social distancing, what about communities with small population and distances. Similarly, the community where the population is very dense, it is impossible for social distancing. Then, they are recommended frequent hand washing, which will be difficult for the people that the area is difficult to obtain water. Values followed by the people of a particular culture is a norm or customary law. Customary law is traditional that is down from generation to generation to the present-day, situation remains in force and maintained by the community concerned; magical-religious, means that the conduct of the law or its legal method relates to the belief in the 
unseen or magical animism-dynamism; belief in the spirits of the ancestor; belief in God; communal; it means prioritizing the common interest; concrete means can be seen, open and simple; it can be changed and the adjusting means dynamic; it is not codified that is largely unwritten; and it is deliberation and consensus [11].

Concerning the handling to prevent the spread and transmission of Covid-19, the government should be comprehensive, that is also involving the community based on each culture. Indonesian people are struggling to prevent the spread and transmission of Covid-19 in their way. For example, the community Banualemo in South Sulawesi, working together to make the liquid disinfectant from natural ingredients. The fluid to eradicate germs and disease was then modified according to the development of the era to combat the coronavirus that is currently endemic. The liquid disinfectant also is used to purify themselves and chase away evil spirits, especially for women who will be married. Evil spirits that are also called "grandma", including a type of virus that is so small that it's invisible. The activity of the community Banualemo has been doing for generations from their ancestors [12].

Besides, to prevent the spread and transmission of Covid19, the government should involve traditional leaders. The involvement of the traditional leaders will bring significant impact as when the suggestion comes from leaders of cultural circles or their own, of course, they will be more to listen to, obey, and implement [13]. They assumed that the advice was following the values they believe.

\section{CONCLUSION}

Indonesia is one country that is experiencing a pandemic have established a variety of legal instruments to prevent the spread and transmission of Covid-19 and medical. Similarly, recommendations to the community so always keep hygiene with frequent hand washing, wear a mask, to do the social distance, and work from home.

However, the implementation of legal instruments and recommendations is not achieving government expectations. The expectations that have not been achieving are seen from the high number of cases in Indonesia. It is due to people ignoring the rules and advice of the government, for example, traveling, gathering, or not using a mask.

Yet the achievement of expectations because the government has yet to harness the potential of culture. Whereas the potential of culture is having a great effect on the community because culture contains values that are believed, understood, and appreciated by the people. Also, the government does not involve the traditional leaders as a community leader of a particular culture. People will be listening and obedient to the leader of their customs because according to what they believed.
Therefore, based on the history of the pandemic that never happened in the world and especially in Indonesia, the handling must be comprehensive. That is, the government not only to apply the rules nationally but also take advantage of the potential - cultures that exist in Indonesia. Considering the cultural values, Indonesia is a country that has a diversity of cultures.

\section{ACKNOWLEDGMENT}

This research was supported financially by the faculty of Law Bandung Islamic University. Also, we would like to thank the faculty of law for allowing us to examine the importance of the involvement of cultural background to overcome the pandemic Covid-19 by supporting to write this article. Also, we would like to thank anonymous reviewers for the input and comments while assessing our manuscript and grateful for the work they do.

\section{REFERENCES}

[1] WHO, WHO Coronavirus (COVID-19) Dashboard [Online] retrieved from: https://covid19. who.int/

[2] Kementerian Kesehatan Republik Indonesia, [Online] retrieved from: https://covid19.kemkes.go.id/situasi-infeksi-emerging/info-coronavirus/situasi-terkini-perkembangan-coronavirus-disease-covid-19-07november-2020

[3] Universitas Gadjah Mada, Pakar UGM Jelaskan Penyebab Masyarakat Melanggar Protokol Kesehatan Covid-19 [Online] retrieved from: https://www.ugm.ac.id/id/berita/20052-pakar-ugm-jelaskan-penyebabmasyarakat-melanggar-protokol-kesehatan-covid-19

[4] Kagama, Penyebab Masyarakat Sulit Mematuhi Protokol Kesehatan [online] retrieved from: http://kagama.co/penyebab-masyarakat-sulitmematuhi-protokol-kesehatan

[5] Amirudin and Z. Asikin, Pengantar Metode Penelitian Hukum. Jakarta: PT. Raja Grafindo Persada, 2003, p. 25.

[6] S.R. Suminar and H.M.F. Mufidi, "The Indonesian Law Perspective on the Authority of Beauty Practitioners in Performing Aesthetic Plastic Surgery," Advances in Social Science, Education and Humanities Research, vol. 307, Atlantis Press, 2019, p. 55

[7] Kamus Besar Bahasa Indonesia Daring, Kementerian Pendidikan dan kebudayaan.

[8] S. Pranawa, Memahami Struktur Masyarakat Indonesia, Sosiologika No. 3, Juni 2005, p. 1 .

[9] Y. Anwar and Adang, Sosiologi Untuk Universitas, Refika Aditama, 2017, p. 179.

[10] R.K.R. Hammar, Peran Kepemimpinan Dan Kearifan Masyarakat Hukum Adat Dalam Penanggulangan Covid 19, LSHI, 2020, p. 175.

[11] A.S.M. Pide, Relevansi Hukum Adat Sebagai Instrumen Upaya Pencegahan Covid-19, LSHI, 2020, p. 235-236.

[12] Virus corona dan kearifan lokal: Bilik sterilisasi dari daun sirih, sayur lodeh untuk tolak bahaya sampai jaga jarak ke hilir sungai, https://www.bbc.com/indonesia/indonesia-52242436

[13] Penanganan Wabah Covid-19 Dengan Pendekatan Budaya, https://kebudayaan.kemdikbud.go.id/bpnbkepri/penanganan-wabahcovid-19-dengan-pendekatan-budaya/ 